\title{
Proliferative kidney disease in rainbow trout: time- and temperature-related renal pathology and parasite distribution
}

\author{
Kathrin Bettge, Thomas Wahli, Helmut Segner, Heike Schmidt-Posthaus* \\ Centre for Fish and Wildlife Health, Institute of Animal Pathology, University of Berne, Laenggassstrasse 122, \\ PO Box 8466, 3001 Berne, Switzerland
}

\begin{abstract}
Proliferative kidney disease is a parasitic infection of salmonid fishes caused by Tetracapsuloides bryosalmonae. The main target organ of the parasite in the fish is the kidney. To investigate the influence of water temperature on the disease in fish, rainbow trout Oncorhynchus mykiss infected with $T$. bryosalmonae were kept at $12^{\circ} \mathrm{C}$ and $18^{\circ} \mathrm{C}$. The number of parasites, the type and degree of lesions in the kidney and the mortality rate was evaluated from infection until full development of disease. While mortality stayed low at $12^{\circ} \mathrm{C}$, it reached $77 \%$ at $18^{\circ} \mathrm{C}$. At $12^{\circ} \mathrm{C}$, pathological lesions were dominated by a multifocal proliferative and granulomatous interstitial nephritis. This was accompanied by low numbers of $T$. bryosalmonae, mainly located in the interstitial lesions. With progression of the disease, small numbers of parasites appeared in the excretory tubuli, and parasite DNA was detected in the urine. Parasite degeneration in the interstitium was observed at late stages of the disease. At $18^{\circ} \mathrm{C}$, pathological lesions in kidneys were more severe and more widely distributed, and accompanied by significantly higher parasite numbers. Distribution of parasites in the renal compartments, onset of parasite degeneration and time course of appearance of parasite DNA in urine were not clearly different from the $12^{\circ} \mathrm{C}$ group. These findings indicate that higher mortality at $18^{\circ} \mathrm{C}$ compared to $12^{\circ} \mathrm{C}$ is associated with an enhanced severity of renal pathology and increased parasite numbers.
\end{abstract}

KEY WORDS: Tetracapsuloides bryosalmonae $\cdot$ Kidney histopathology $\cdot$ Temperature $\cdot$ Proliferative kidney disease $\cdot$ Rainbow trout $\cdot$ Parasite localization

\section{INTRODUCTION}

Proliferative kidney disease (PKD) is a parasitic infection of salmonid fishes caused by Tetracapsuloides bryosalmonae (Myxozoa: Malacosporea) (Feist \& Bucke 1993, Hedrick et al. 1993, Canning et al. 2000, Okamura et al. 2001). Clinical disease leads to high mortalities in affected fish (Ferguson \& Ball 1979, Clifton-Hadley et al. 1986). PKD is discussed as one factor contributing to the decrease of wild salmonid populations in Switzerland (Wahli et al. 2002, 2007, Burkhardt-Holm et al. 2005) and Norway (Sterud et al. 2007).

The parasite life-cycle, as far as known to date, includes different species of bryozoans as invertebrate hosts (Anderson et al. 1999, Longshaw et al. 1999, Okamura et al. 2001), and salmonids as vertebrate hosts (Feist \& Bucke 1993, Hedrick et al. 1993). Tetracapsuloides bryosalmonae infects the fish through skin and gills (Feist et al. 2001, Longshaw et al. 2002) and after systemic circulation enters the main target organ, the kidney (Kent \& Hedrick 1985). In the kidney $T$. bryosalmonae undergoes multiplication and differentiation from extrasporogonic to sporogonic stages (Kent \& Hedrick 1985). Infected salmonids can probably excrete spores via the urine (Kent \& Hedrick 1985, Hedrick et al. 2004) and spores excreted by brown trout Salmo trutta or brook trout Salvelinus fontinalis can reinfect bryozoans (Morris \& Adams 2006, Grabner \& El-Matbouli 2008).

The disease caused by Tetracapsuloides bryosalmonae is temperature dependent, as clinical signs 
and PKD related mortality increase at water temperatures above $15^{\circ} \mathrm{C}$, whereas below $15^{\circ} \mathrm{C}$ low mortality rates are reported (Ferguson \& Ball 1979, Ferguson 1981, Clifton-Hadley et al. 1986). In parallel with the occurrence of clinical disease signs at water temperatures above $15^{\circ} \mathrm{C}$, severe pathological lesions are observed in infected fish (Kent \& Hedrick 1985, Clifton-Hadley et al. 1987, Morris et al. 2005). Currently it is not known whether and how parasite development in the fish and the pathological response to the infection change with temperature. Such knowledge could be important for understanding the reasons for the increased mortality of PKD-infected fish at elevated water temperatures. As the most marked changes in $T$. bryosalmonae infected fish are found in the kidney (Kent \& Hedrick 1985, Clifton-Hadley et al. 1987, Morris et al. 2005), this study concentrated on renal disease.

The aim of the present study was to investigate and compare renal pathology as well as parasite localization in different renal compartments including possible transfer into the urine at 2 temperatures, $12^{\circ} \mathrm{C}$ and $18^{\circ} \mathrm{C}$, which are characterized by different levels of clinical disease manifestation and mortality. The sequence of pathological changes in kidneys of infected fish was studied by histopathology. The localization of parasites in the kidney was determined by histology, immunohistochemistry and in situ hybridization. Urinary excretion of parasite DNA was assessed by real-time PCR.

\section{MATERIALS AND METHODS}

Experimental exposure and sampling. This study used $4250+$ rainbow trout Oncorhynchus mykiss (mean size of $8.3 \pm 0.52 \mathrm{~cm}$ ) originating from a commercial trout farm with water temperature below $12{ }^{\circ} \mathrm{C}$ and no history of PKD. Before exposure, 5 randomly sampled fish were subjected to macroscopic and histological examinations for signs of PKD and tested for the presence of Tetracapsuloides bryosalmonae by realtime PCR. The remaining 420 trout were exposed in September to water from a river with water temperature ranging from 12 to $16^{\circ} \mathrm{C}$, regularly shown to harbor $T$. bryosalmonae-infected fish in previous years. Five days after the start of exposure 20 randomly sampled fish were investigated for the presence of $T$. bryosalmonae using real-time PCR. The remaining trout were transferred to the laboratory at the Centre for Fish and Wildlife Health (FIWI) and split into 2 groups consisting of 200 fish. Fish were kept in $100 \mathrm{l}$ tanks with a flow-through system and constant aeration. The transfer to the experimental temperatures of $12^{\circ} \mathrm{C}$ and $18^{\circ} \mathrm{C}$ was carried out over $1 \mathrm{~d}$. Oxygen con- centration in all tanks was $\geq 8 \mathrm{mg} \mathrm{l}^{-1}$ during the experimental period. Fish were fed commercial trout pellets (HOKOVIT, Bützberg) with a daily food ratio of 1 to $2 \%$ of body weight. Mortalities were recorded daily and dead fish were subjected to parasitological and bacteriological examination and a complete necropsy as described below. Fish from the same trout farm without exposure to the river were held as negative controls at $12^{\circ} \mathrm{C}$ and $18^{\circ} \mathrm{C}$ in the laboratory at the FIWI. These fish were not infected with $T$. bryosalmonae, as measured by repeated macroscopic examinations and by real-time PCR.

In each experimental group, 5 samples with 10 fish were taken at weekly or $14 \mathrm{~d}$ intervals for $6 \mathrm{wk}$, resulting in 7 samples for each group (Table 1). Fish were euthanized in buffered 3-aminobenzoic acid ethyl ester (MS 222 ${ }^{\circledR}$, Argent Chemical Laboratories). A standard necropsy was performed on all individuals. Fresh mounts of skin and gill samples and the intestinal content were examined microscopically for the presence of parasites. For bacteriological examination, samples from liver, spleen and kidney were cultured on blood agar plates (Bio Merieux) and bromothymolblue-lactose-agar plates. Fish were examined for external darkening, exophthalmia, anemic gills, kidney swelling, or ascites. Kidneys were removed and dissected vertically. One half was fixed in $10 \%$ buffered formalin for histopathological and immunohistochemical examination (IHC) and in situ hybridization (ISH). The other half of the kidney was frozen in liquid nitrogen for real-time PCR analyses.

After river water exposure, fish showed an infection with Ichthyophthirius multifilis until Day 19. These fish

Table 1. Tetracapsuloides bryosalmonae-infection experiment. Sampling schedule. From Day 0 to Day 5 post-exposure (pe) rainbow trout Oncorhynchus mykiss were exposed to river water known to harbour $T$. bryosalmonae. After transfer into the laboratory, trout were split into 2 groups and held in tap water at $12^{\circ} \mathrm{C}$ or $18^{\circ} \mathrm{C}$. IHC: immunohistochemistry; ISH: in situ hybridization. Values indicate number of fish investigated using each analytical technique

\begin{tabular}{|lccccc|}
\hline Day pe & $\begin{array}{c}\text { Temperature } \\
\left({ }^{\circ} \mathrm{C}\right)\end{array}$ & $\begin{array}{c}\text { Total fish } \\
\text { sampled }\end{array}$ & $\begin{array}{c}\text { Real-time } \\
\text { PCR }\end{array}$ & IHC & ISH \\
\hline 0 & $<12$ & 5 & 5 & 0 & 0 \\
5 & $12-16$ & 20 & 20 & 10 & 8 \\
12 & 12 & 10 & 10 & 5 & 5 \\
& 18 & 10 & 10 & 5 & 4 \\
19 & 12 & 10 & 10 & 5 & 4 \\
& 18 & 10 & 10 & 5 & 5 \\
26 & 12 & 10 & 10 & 5 & 5 \\
& 18 & 10 & 10 & 6 & 6 \\
33 & 12 & 10 & 10 & 5 & 5 \\
& 18 & 10 & 10 & 4 & 5 \\
47 & 12 & 10 & 10 & 5 & 5 \\
& 18 & 10 & 10 & 5 & 5 \\
\hline
\end{tabular}


were treated with $3 \% \mathrm{NaCl}$ in a bath-treatment and no mortalities related to $I$. multifiliis were recorded.

To analyse fish urine for the presence of parasite DNA, at each sampling, 2 batches of 5 fish of each group were held for 30 min in 21 tanks containing tap water with no flow through. The $30 \mathrm{~min}$ incubation period was selected on the basis of physiological data indicating that salmonid fish release urine approximately each 30 min (Curtis \& Wood 1991). After removing fish, water was filtered through a 4 to $12 \mu \mathrm{m}$ filter paper mesh (Schleicher \& Schuell MicroScience). The filter was stored at $-20^{\circ} \mathrm{C}$ until further analysis.

Histopathology, immunohistochemistry and in situ hybridization. Fixed samples were paraffin-embedded and 3 consecutive sections of $3 \mu \mathrm{m}$ thickness were prepared. The first slide was stained with haematoxylineosin (H\&E) for histopathological examination. The second slide was used for IHC staining and the third slide for ISH.

H\&E stained slides were examined by a Zeiss-KF2 light microscope (Zeiss). Histopathological changes of the whole kidney section were classified from 0 (no alterations) to +++ (severe alterations as infiltration with high numbers of macrophages, multiple areas of haemorrhage, severe proliferation of the haematopoietic tissue, widespread necrosis or vasculitis with some thrombi formations).

For IHC, a monoclonal anti-Tetracapsuloides bryosalmonae (PKX) antibody (AquaMAb-P01, Aquatic Diagnostics) was used. Staining was done according to the protocol of Adams et al. (1992) with minor modifications. Unstained sections were incubated overnight using an antibody dilution of $1 / 100$. Non-specific background staining was blocked with goat serum. A biotin-streptavidin-horseradish peroxidase staining kit (Kit Dako LSAB 2 System HRP Code Nr. K0675; DakoCytomation) followed by AEC (amino-ethyl-carbazole) staining (Dako AEC K3464) was used to visualize antibody-antigen complexes. Counterstaining of these sections was not performed. Kidney tissue of a fish known to be PKD-positive was used as a positive control. Slides incubated without the first antibody were used as negative controls.

For ISH, digoxigenin-labelled probes were produced according to Longshaw et al. (2002). ISH of DNA probes to Tetracapsuloides bryosalmonae was performed according to the protocol published by Longshaw et al. (2002) with minor modifications. After overnight incubation at $42^{\circ} \mathrm{C}$, the hybridization chambers were removed and slides were washed in $2 \times$ SSC for $20 \mathrm{~min}$, followed by exposure to $0.1 \times \mathrm{SSC}$ at $42^{\circ} \mathrm{C}$ for $20 \mathrm{~min}$ and an additional washing step in TBS. Nonspecific binding was blocked by incubation with $6 \%$ skimmed milk for $1 \mathrm{~h}$.
The next steps followed the protocol published by Longshaw et al. (2002). The slides were counterstained with Bismarck Brown Y for 1 min. Two slides with kidney of a fish known to be PKD-positive were used as controls, one slide as a positive control with the digoxigenin-labelled probe, the other slide as negative control using a non-digoxigenin-labelled probe in the hybridization buffer. For evaluation of IHC and ISH, 6 viewing fields (magnification: 160×) per slide and fish were randomly selected and the number of parasites were counted using light microscopy on a Zeiss-KF2 light microscope. Parasites were grouped according to location (renal interstitial tissue, vessels, tubules). For each time point the mean value for each location of all examined fish per temperature group was used.

Real-time PCR for detection of parasite DNA in fish urine and kidney tissue. For extracting genomic DNA from fish urine, the uppermost layer of a filter (used for 5 fish each) was removed with a scalpel blade. Genomic DNA including parasite DNA was extracted from that filter layer with DNAzol (Lucerna). For detection of parasite DNA in the kidneys, homogenized kidney tissue was used for genomic DNA extraction with DNAzol. The yield obtained from all samples was determined by spectrophotometry using a NanoDrop photometer (NanoDrop Technologies).

A 435 bp nucleotide sequence of the 18S rDNA gene of Tetracapsuloides bryosalmonae was chosen from GenBank (Accession No. AF190669; Canning et al. 1999) to be cloned into the $\mathrm{pCR}{ }^{\circledR}$-TOPO ${ }^{\circledR}$ vector using the TOPO TA Cloning ${ }^{\circledR}$ Kit (Invitrogen) following the manufacturer's protocol. The vector plasmid DNA was purified with the QIAprep Miniprep ${ }^{\circledR}$ kit (Qiagen) and resuspended in $8 \mathrm{mM} \mathrm{NaOH}$. The yield was determined by spectrophotometry using the NanoDrop photometer. The plasmid DNA was amplified and sequenced in order to verify the sequence of the insert.

Forward and reverse primers were designed to amplify a $73 \mathrm{bp}$ region of the $18 \mathrm{~S}$ rDNA sequence of Tetracapsuloides bryosalmonae. Primers and probe (Table 2) were constructed by Microsynth (Balgach). The TaqMan probe was labeled at the $5^{\prime}$ end with the reporter dye 6-carboxyfluorescein (FAM) and at the 3' end with the quencher dye 6-carboxytetramethylrhodamine (TAMRA). To test the specificity of the amplification of the probe and primer combination, a

Table 2. Tetracapsuloides bryosalmonae-primers and probe. Sequences used for real-time PCR. bp: base pairs

\begin{tabular}{|llc|}
\hline Primer/probe & Sequence $\left(5^{\prime}-3^{\prime}\right)$ & Size $(\mathrm{bp})$ \\
\hline PKDtaqf1 & GCGAGATTTGTTGCATTTAAAAAG & 24 \\
PKDtaqr1 & GCACATGCAGTGTCCAATCG & 20 \\
ProbePKD & CAAAATTGTGGAACCGTCCGACTACGA & 27 \\
\hline
\end{tabular}


conventional PCR according to Kent et al. (1998) was performed and the products were checked on an agarose gel for amplification and molecular weight. The quantitative real-time PCR amplification was performed as follows: the reaction volume of $25 \mu \mathrm{l}$ containing 1× TaqMan universal Master Mix (Applied Biosystems), $300 \mathrm{nM}$ forward primer, $300 \mathrm{nM}$ reverse primer, $200 \mathrm{nM}$ fluorescent labeled probe, and $2 \mu \mathrm{g}$ extracted DNA from the trout kidney as template. Amplification was done in an $\mathrm{Mx} 4000^{\circledR}$ Multiplex Quantitative PCR System (Stratagene). The amplification conditions consisted of initial denaturation at $95^{\circ} \mathrm{C}$ for $10 \mathrm{~min}$, followed by 45 cycles of $15 \mathrm{~s}$ at $95^{\circ} \mathrm{C}$ and $1 \mathrm{~min}$ at $60^{\circ} \mathrm{C}$. All samples were analysed in duplicate.

The cloned region of the 18S rDNA gene of Tetracapsuloides bryosalmonae was used for the generation of standard curves. To calculate the copy numbers of the standard curve, nucleotide length and plasmid concentration were used (Yin et al. 2001). From a stock solution, a 10-fold serial dilution in buffer $(8 \mathrm{mM}$ $\mathrm{NaOH}$ ) was prepared, subjected to real-time PCR and the obtained threshold cycle values $\left(C_{t}\right)$ were plotted against the quantity of the plasmid DNA. The assay conditions to measure the samples of the standard curve were identical to those used for the fish samples. The regression equation obtained for the standard curve of the 18S rDNA of $T$. bryosalmonae was then used to convert the measured $C_{\mathrm{t}}$ value of an unknown sample into copy numbers of parasite DNA. A reference sample with known copy numbers of plasmid DNA was measured together with the samples to calibrate each run. The PCR product of the reference sample was sequenced to verify the specificity of the realtime PCR.

Statistical analyses. Using IHC or ISH, the parasite stages in the different locations of the kidney were counted at all sampling points in the 2 groups $\left(12^{\circ} \mathrm{C}\right.$ and $18^{\circ} \mathrm{C}$ treatment) by evaluation of 6 randomly selected fields on each slide. The results were tested for normal distribution with the Skewness, Kurtosis and Omnibus Normality tests. The 2 groups $\left(12^{\circ} \mathrm{C}\right.$ and $18^{\circ} \mathrm{C}$ group) were compared to each other at each sampling point and for differences between IHC and ISH counts. Both methods were also compared to each other. As the values were not normally distributed, we used the Mann-Whitney $U$ or Wilcoxon rank-sum test to analyze for significant differences. Cumulative mortality was calculated using the number of fish that died during the experiment minus the ones used for sampling. The cumulative mortalities of the different groups were compared and tested for significant differences using the chi-square test. For all statistical tests, NCSS 2001 (Hintze 2006) was used.

\section{RESULTS}

\section{Mortality}

In the infected groups, all fish at all sampling points tested positive by means of real-time PCR for Tetracapsuloides bryosalmonae (100\% prevalence). The cumulative mortality of fish was significantly different between the temperature groups ( $p \leq 0.01$ ) (Fig. 1). In the group kept at $12{ }^{\circ} \mathrm{C}, 5.6 \%$ died, while at $18^{\circ} \mathrm{C}$ cumulative mortality reached $77.1 \%$ at the end of the experiment. Parasitological examination of dead fish revealed no external or intestinal parasites. In most cases no bacteria could be isolated from samples from the kidney, spleen and liver examined by bacteriology. Sporadically, single colonies of mixed bacteria were isolated, but were not considered as a contributing factor to mortality. Histopathological examination revealed no changes other than those due to infection with $T$. bryosalmonae.

\section{Pathological lesions and parasite distribution}

At Day 0, before exposure to river water, no macroscopic or histological changes in the kidney were observed and no Tetracapsuloides bryosalmonae DNA was detectable with real-time PCR in the 5 fish sampled. After the 5 d exposure to river water all examined rainbow trout kidneys $(n=20)$ were confirmed positive for $T$. bryosalmonae by real-time PCR. At this time point, 2 out of 20 fish sampled showed macroscopically slightly enlarged kidneys. Histologically we observed renal haematopoietic hyperplasia and mild multifocal infiltration (mainly macrophages). In all fish sampled, small numbers of single-cell parasites were found by $\mathrm{H} \& \mathrm{E}$ in renal blood vessels and in the haematopoietic interstitial tissue of the kidney. The presence of a small number

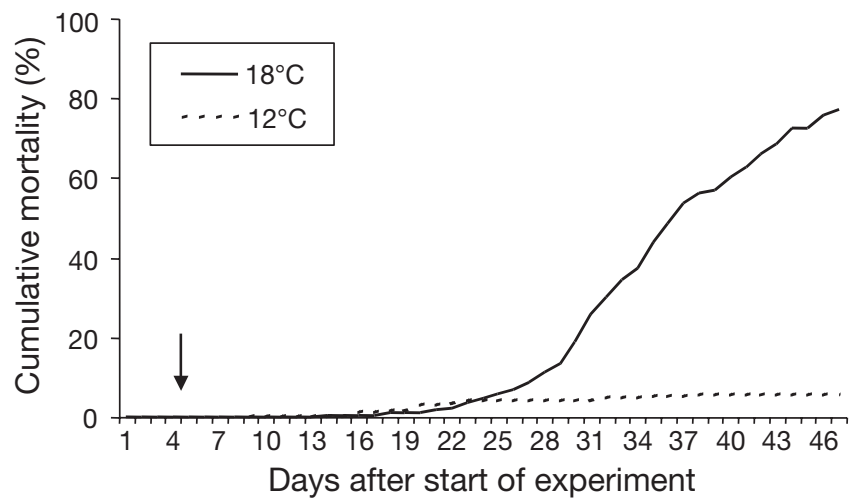

Fig. 1. Tetracapsuloides bryosalmonae-induced cumulative mortality of rainbow trout Oncorhynchus mykiss kept at $12^{\circ} \mathrm{C}$ and $18^{\circ} \mathrm{C}$. Arrow indicates time point when trout were separated into 2 groups 
Table 3. Tetracapsuloides bryosalmonae in kidneys of rainbow trout Oncorhynchus mykiss held at $12^{\circ} \mathrm{C}$ and $18^{\circ} \mathrm{C}$. Comparison of mean parasite numbers assessed on immunohistochemistry (IHC)-stained and in situ hybridization (ISH)-stained slides in all kidney compartments. Numbers in brackets show lowest and highest values of parasites counted in the 6 areas per fish per sample

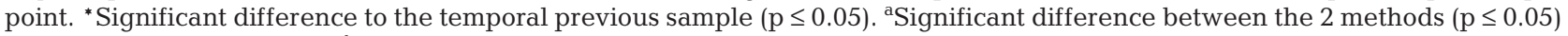
used on the same samples. ${ }^{\mathrm{b}}$ Significant difference between temperatures at the same sample point and with the same method $(\mathrm{p} \leq 0.05)$. pe: post exposure

\begin{tabular}{|c|c|c|c|c|c|c|c|c|c|c|c|c|}
\hline \multirow{3}{*}{ Day pe } & \multicolumn{4}{|c|}{ Vessels } & \multicolumn{4}{|c|}{ Interstitium } & \multicolumn{4}{|c|}{ - Tubules } \\
\hline & \multicolumn{2}{|c|}{$\mathrm{IHC}$} & \multicolumn{2}{|c|}{ ISH } & \multicolumn{2}{|c|}{$\mathrm{IHC}$} & \multicolumn{2}{|c|}{ ISH } & \multicolumn{2}{|c|}{$\mathrm{IHC}$} & \multicolumn{2}{|c|}{ ISH } \\
\hline & $12^{\circ} \mathrm{C}$ & $18^{\circ} \mathrm{C}$ & $12^{\circ} \mathrm{C}$ & $18^{\circ} \mathrm{C}$ & $12^{\circ} \mathrm{C}$ & $18^{\circ} \mathrm{C}$ & $12^{\circ} \mathrm{C}$ & $18^{\circ} \mathrm{C}$ & $12^{\circ} \mathrm{C}$ & $18^{\circ} \mathrm{C}$ & $12^{\circ} \mathrm{C}$ & $18^{\circ} \mathrm{C}$ \\
\hline 5 & $\begin{array}{c}0.05 \\
(0-2)\end{array}$ & $\begin{array}{c}0.05 \\
(0-2)\end{array}$ & $\begin{array}{c}0.10 \\
(0-2)\end{array}$ & $\begin{array}{c}0.10 \\
(0-2)\end{array}$ & $\begin{array}{c}0.07 \\
(0-1)\end{array}$ & $\begin{array}{c}0.07 \\
(0-1)\end{array}$ & $\begin{array}{l}1.15^{\mathrm{a}} \\
(0-7)\end{array}$ & $\begin{array}{l}1.15^{\mathrm{a}} \\
(0-7)\end{array}$ & $\begin{array}{c}0.00 \\
(0-0)\end{array}$ & $\begin{array}{c}0.00 \\
(0-0)\end{array}$ & $\begin{array}{c}0.00 \\
(0-0)\end{array}$ & $\begin{array}{c}0.00 \\
(0-0)\end{array}$ \\
\hline 12 & $\begin{array}{c}0.00 \\
(0-0)\end{array}$ & $\begin{array}{l}1.33^{* b} \\
(0-20)\end{array}$ & $\begin{array}{c}0.07 \\
(0-1)\end{array}$ & $\begin{array}{c}0.08 \\
(0-2)\end{array}$ & $\begin{array}{c}0.03 \\
(0-1)\end{array}$ & $\begin{array}{l}5.30 * \mathrm{~b} \\
(0-59)\end{array}$ & $\begin{array}{l}0.73^{\mathrm{a}} \\
(0-5)\end{array}$ & $\begin{array}{c}11.79 * a b \\
(0-89)\end{array}$ & $\begin{array}{c}0.00 \\
(0-0)\end{array}$ & $\begin{array}{c}0.03 \\
(0-1)\end{array}$ & $\begin{array}{c}0.00 \\
(0-0)\end{array}$ & $\begin{array}{c}0.25 \\
(0-2)\end{array}$ \\
\hline 19 & $\begin{array}{l}0.23^{*} \\
(0-3)\end{array}$ & $\begin{array}{c}1.23 \\
(0-15)\end{array}$ & $\begin{array}{l}1.38^{*} \\
(0-12)\end{array}$ & $\begin{array}{l}2.27^{*} \\
(0-11)\end{array}$ & $\begin{array}{l}1.00^{*} \\
(0-6)\end{array}$ & $\begin{array}{c}6.67 \\
(0-65)\end{array}$ & $\begin{array}{c}1.75 \\
(0-11)\end{array}$ & $\begin{array}{l}18.73^{\mathrm{ab}} \\
(1-84)\end{array}$ & $\begin{array}{c}0.00 \\
(0-0)\end{array}$ & $\begin{array}{c}0.00 \\
(0-0)\end{array}$ & $\begin{array}{c}0.25 \\
(0-6)\end{array}$ & $\begin{array}{c}0.03 \\
(0-1)\end{array}$ \\
\hline 26 & $\begin{array}{c}0.63 \\
(0-6)\end{array}$ & $\begin{array}{l}4.08^{* b} \\
(0-38)\end{array}$ & $\begin{array}{c}0.23 \\
(0-4)\end{array}$ & $\begin{array}{c}6.50^{\mathrm{b}} \\
(0-29)\end{array}$ & $\begin{array}{c}0.47 \\
(0-3)\end{array}$ & $\begin{array}{c}4.67^{\mathrm{b}} \\
(0-31)\end{array}$ & $\begin{array}{c}3.07 \\
(0-19)\end{array}$ & $\begin{array}{l}84.64 * a b \\
(24-171)\end{array}$ & $\begin{array}{c}0.03 \\
(0-1)\end{array}$ & $\begin{array}{c}0.06 \\
(0-1)\end{array}$ & $\begin{array}{c}0.03 \\
(0-1)\end{array}$ & $\begin{array}{c}0.17 \\
(0-2)\end{array}$ \\
\hline 33 & $\begin{array}{l}2.50^{*} \\
(0-15)\end{array}$ & $\begin{array}{l}9.83^{* b} \\
(0-37)\end{array}$ & $\begin{array}{c}0.33 \\
(0-6)\end{array}$ & $\begin{array}{c}7.50^{\mathrm{b}} \\
(0-47)\end{array}$ & $\begin{array}{c}7.57^{*} \\
(0-37)\end{array}$ & $\begin{array}{l}48.25^{* b} \\
(3-100)\end{array}$ & $\begin{array}{l}12.30^{*} \\
(0-64)\end{array}$ & $\begin{array}{l}115.54^{\mathrm{ab}} \\
(6-257)\end{array}$ & $\begin{array}{c}0.00 \\
(0-0)\end{array}$ & $\begin{array}{c}0.04 \\
(0-1)\end{array}$ & $\begin{array}{c}0.30 \\
(0-1)\end{array}$ & $\begin{array}{l}0.79^{a} \\
(0-4)\end{array}$ \\
\hline 47 & $\begin{array}{c}0.97 \\
(0-6)\end{array}$ & $\begin{array}{c}4.27 \\
(0-30)\end{array}$ & $\begin{array}{l}1.17 \\
(0-9)\end{array}$ & $\begin{array}{c}4.93 \\
(0-23)\end{array}$ & $\begin{array}{c}4.87 \\
(0-14)\end{array}$ & $\begin{array}{c}52.00^{\mathrm{b}} \\
(0-200)\end{array}$ & $\begin{array}{c}7.40 \\
(1-30)\end{array}$ & $\begin{array}{l}103.73^{\mathrm{ab}} \\
(0-227)\end{array}$ & $\begin{array}{c}0.10 \\
(0-2)\end{array}$ & $\begin{array}{c}0.10 \\
(0-1)\end{array}$ & $\begin{array}{c}0.07 \\
(0-2)\end{array}$ & $\begin{array}{l}0.60^{\mathrm{a}} \\
(0-3)\end{array}$ \\
\hline
\end{tabular}

of parasites in renal tissue at Day 5 was confirmed by IHC and ISH (Table 3).

\section{$12^{\circ} \mathrm{C}$ group}

A first sampling after transfer from river water to the laboratory was made at Day 12 post-exposure (pe) (i.e. $7 \mathrm{~d}$ after transfer from field to laboratory). At this time point, 3 out of 10 sampled fish displayed macroscopic signs of PKD, including renal hyperplasia and grayish discoloration of the kidney (Table 4). The frequency of fish displaying macroscopic signs of PKD showed a continuous increase over the study period and reached $90 \%$ at the end of the experiment. Histopathological lesions were present in all examined fish from Day 12 onwards. The most prominent histopathological lesions were seen in the interstitial haematopoietic tissue. At Day 12, few areas with mild proliferation of the haematopoietic tissue and mild infiltration mainly by macrophages were scattered throughout the interstitial tissue. Towards Day 47 these scattered, small areas progressed to a severe multifocal to coalescent proliferative and granulomatous interstitial nephritis with small, poorly circum-
Table 4. Tetracapsuloides bryosalmonae in kidneys of rainbow trout Oncorhynchus mykiss held at $12^{\circ} \mathrm{C}$. Results of macroscopic and histological examination of the kidneys and presence of parasite DNA in the urine measured by real-time PCR. (+): scattered; +: mild alterations; ++: moderate alterations; +++ : severe alterations; nd: not done

\begin{tabular}{|c|c|c|c|c|c|}
\hline & \multicolumn{5}{|c|}{ Day post-exposure } \\
\hline & 12 & 19 & 26 & 33 & 47 \\
\hline \multicolumn{6}{|c|}{ Macroscopic enlargement of the kidneys $(n=10)$} \\
\hline Abundance & + & + & + to ++ & + to ++ & + to ++ \\
\hline Prevalence (\%) & 30 & 60 & 70 & 60 & 90 \\
\hline \multicolumn{6}{|l|}{ Histological changes to the kidneys $(n=5)$} \\
\hline Prevalence (\%) & 100 & 100 & 100 & 100 & 100 \\
\hline \multicolumn{6}{|l|}{ Interstitium } \\
\hline Proliferation of haematopoietic tissue & + & ++ & ++ & ++ & + \\
\hline Infiltration & + & + & + & ++ & ++ \\
\hline Necrosis & & + & + & ++ & + \\
\hline Haemorrhage & & & & & + \\
\hline Single-cell parasites & + & & & & \\
\hline Parasites with daughter cells & & + & + & ++ & ++ \\
\hline Degenerating parasites & & & & & + \\
\hline \multicolumn{6}{|l|}{ Vessels } \\
\hline Hypertrophy of endothelial cells & & & & + & ++ \\
\hline Attachment of inflammatory cells & & & + & ++ & +++ \\
\hline Single-cell parasites in lumen & + & + & & & \\
\hline Parasites with daughter cells in lumen & & & + & + & + \\
\hline Degenerating parasites & & & & & + \\
\hline \multicolumn{6}{|l|}{ Tubules } \\
\hline Tubulonephrosis & & & & + & + \\
\hline Intraluminal stages of parasites & & $(+)$ & $(+)$ & $(+)$ & $(+)$ \\
\hline Real-time PCR & nd & neg & pos & pos & pos \\
\hline
\end{tabular}

scribed areas of necrosis (Table 4). The interstitial lesions remained in a patchy distribution until the end of the experiment. Although low numbers of parasites 

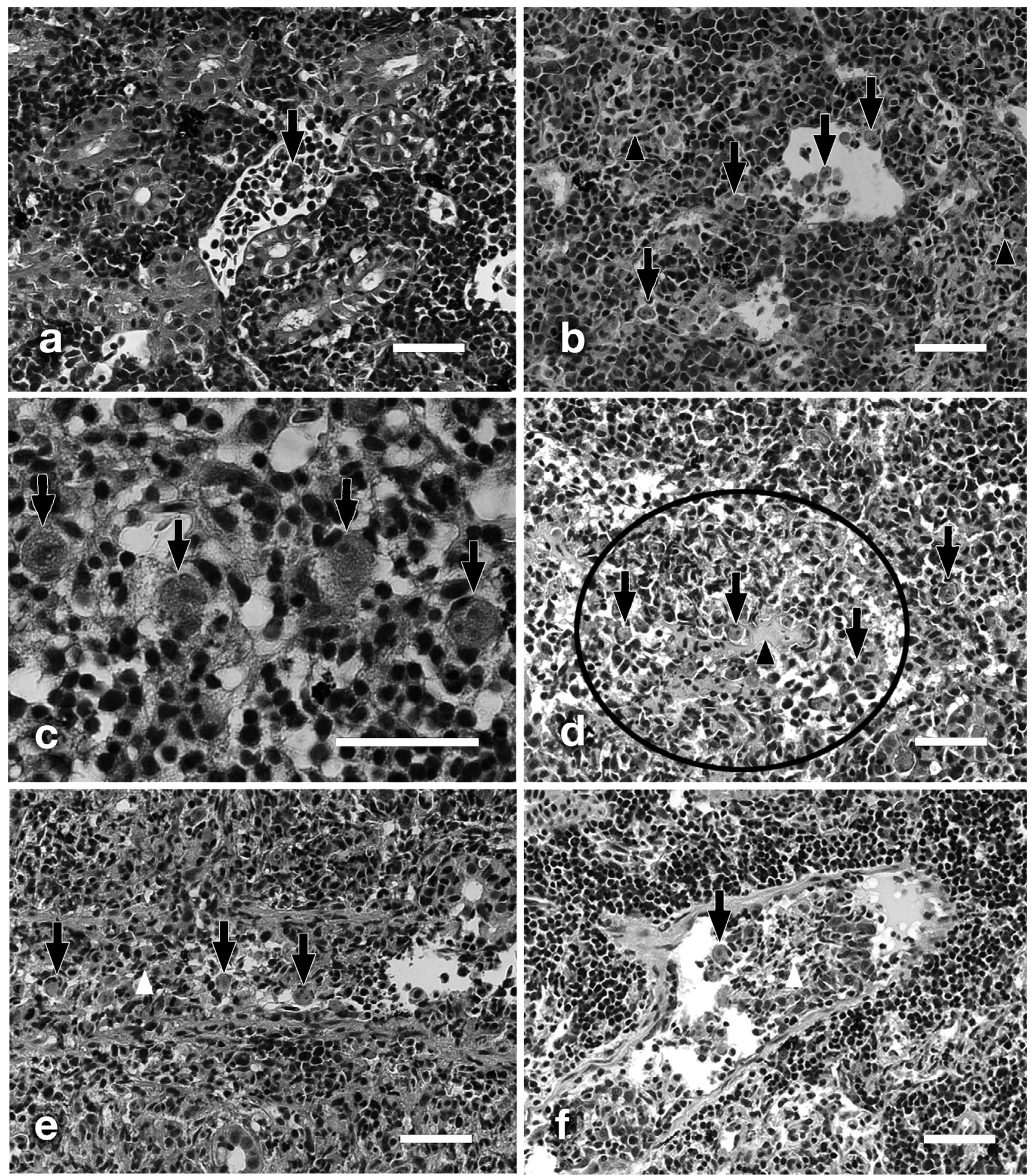

Fig. 2. Tetracapsuloides bryosalmonae-induced histological changes and parasite differentiation in rainbow trout Oncorhynchus mykiss held at $(\mathrm{a}-\mathrm{c}) 12^{\circ} \mathrm{C}$ and $(\mathrm{d}-\mathrm{f}) 18^{\circ} \mathrm{C}$. (a) Parasites (arrow) in an unaltered vessel at Day 19, interstitium unaltered. (b) Parasites (arrows) penetrating vessel wall and attachment of macrophages to parasites in the vessel at Day 26. Interstitium is infiltrated with macrophages and lymphocytes (black arrowheads). (c) Degenerating parasites (arrows) in the interstitium at Day 47. (d) Severe necrosis (black circle) of the interstitium at Day 19, parasites in the interstitium (arrows), and accumulation of fibrin in the necrotic area (black arrowhead). (e) Parasites (arrows) in a severely damaged vessel; lumen filled with a thrombus (white arrowhead) at Day 26. (f) Parasites (arrow) in a vessel; lumen filled with a thrombus (white arrowhead) at Day 47 . All pictures are taken from slides stained with H\&E. Magnification $=(a, b, d-f) 400 \times$, (c) 1000x. All scale bars $=50 \mu \mathrm{m}$ 
were present in the vessels at all sampling points (Fig. 2a), it took until Day 26 to develop hypertrophy of endothelial cells and a mild infiltration with macrophages and lymphocytes in the vessel walls. From Day 26 until the end of the experiment macrophages and lymphocytes surrounded intravascular parasites (Fig. 2b). Tubular lesions, such as dissociation and degeneration of epithelial cells, developed after $33 \mathrm{~d}$. These degenerative tubular lesions were independent of the presence of intraluminal parasites. Histologically, Tetracapsuloides bryosalmonae stages were visible with H\&E staining at all sampling points in the renal interstitium and vessels, and after $19 \mathrm{~d}$ also in the tubular epithelium (Fig. 3a) and tubular lumen (Fig. 3b). While up to Day 12 only single-cell parasites were seen in infected fish, parasites with daughter cells were present at Day 19 and later. In parallel to this change in the parasite status, advanced patholog- ical changes developed in the interstitium. At 47 dpe some parasites in the interstitium and the vessels showed signs of degeneration, such as loss of structural integrity and hypereosinophilia (Fig. 2c). IHC and ISH revealed higher parasite numbers in the interstitium compared to the other kidney compartments at all sampling points. However, the total number remained low (Table 3). At Days 5 and 12, the parasite number in the interstitium as detected by ISH was significantly higher than that assessed by IHC ( $p \geq 0.05)$. At all other time points no significant differences between the 2 methods were seen, neither in vessels nor interstitium, or in tubules. By means of IHC and ISH low numbers of parasites were found in the tubules beginning from Day 19 to the end of the experiment (Table 3, Fig. 3c,d). Parasite DNA in the urine was detectable from Day 26 to Day 47 pe (Table 4).
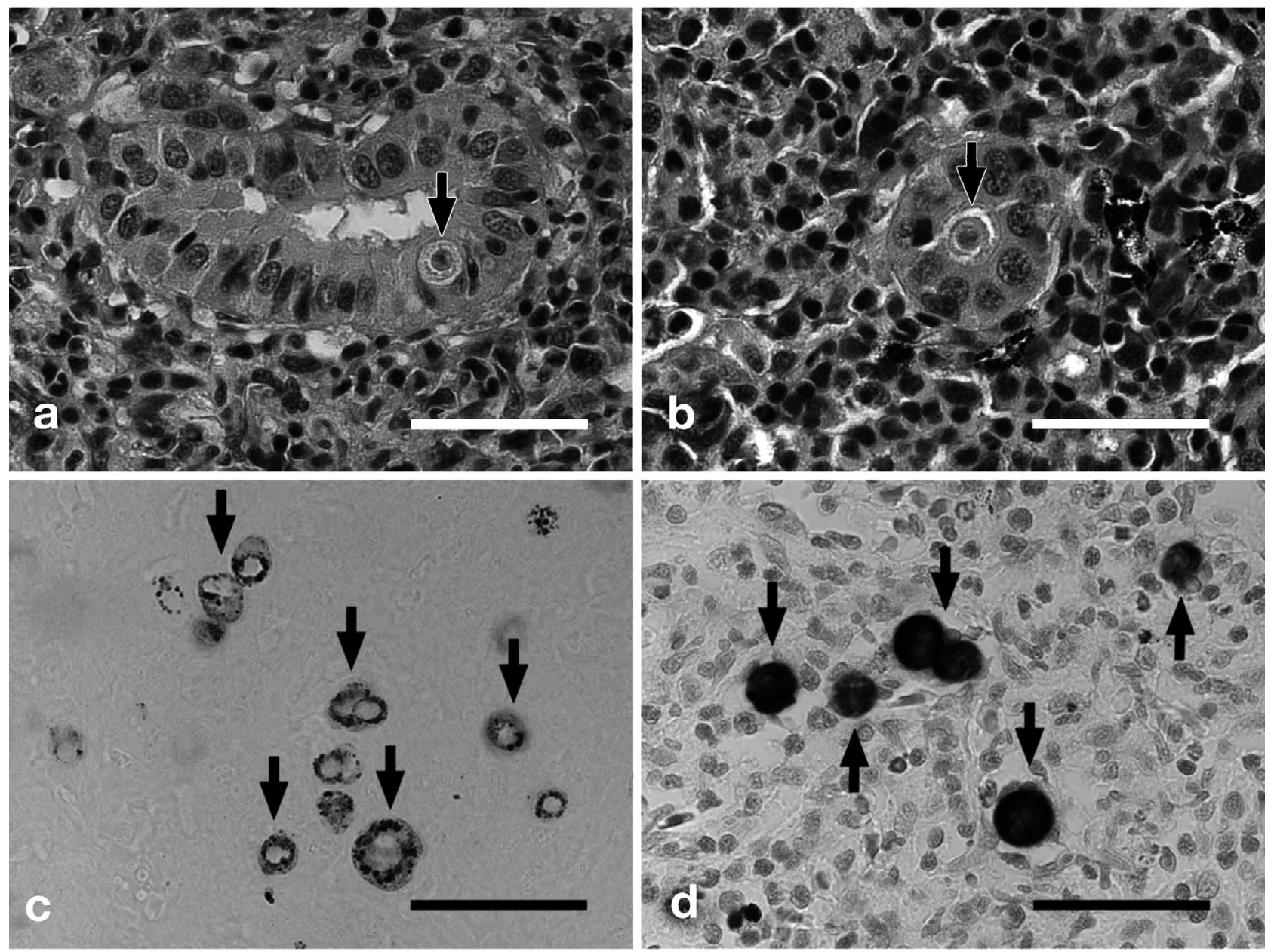

Fig. 3. Tetracapsuloides bryosalmonae in kidneys of infected rainbow trout Oncorhynchus mykiss held at $18^{\circ} \mathrm{C}$. (a) Tubular wall containing a parasite at Day 47 (arrow). (b) Tubular lumen containing a parasite at Day 47 (arrow). (c) Immunohistochemical staining of parasites (arrows) in the interstitium at Day 47. (d) In situ hybridization of the DNA of the parasites in the interstitium (arrows) at Day 26. (a) and (b) were taken from slides stained with H\&E. Magnification = 1000×. All scale bars = 50 $\mu \mathrm{m}$ 


\section{$18^{\circ} \mathrm{C}$ group}

At $18^{\circ} \mathrm{C}$ macroscopic lesions were generally more pronounced than in fish kept at $12^{\circ} \mathrm{C}$. The prevalence of fish with macroscopic signs increased to $100 \%$ at Day 26 and remained at this level until the end of the experiment (Table 5). In the H\&E stained sections, the type of renal lesions was comparable to that of the $12^{\circ} \mathrm{C}$ group. However, fish kept at the higher water temperature showed more severe interstitial and vascular lesions that developed more rapidly. In the haematopoietic tissue a proliferative and granulomatous interstitial nephritis with single cell necrosis was already present 12 dpe. After $19 \mathrm{~d}$ there were multiple poorly circumscribed areas of necrosis in the interstitial tissue (Fig. 2d). Beginning at Day 26 there were large areas of haemorrhage indicating severe vessel damage. The vessel lesions developed earlier and were more prominent compared to the $12^{\circ} \mathrm{C}$ group. After $19 \mathrm{~d}$ endothelial cells were hypertrophied and there was a mild lymphohistiocytic vasculitis. Lesions devel-

Table 5. Tetracapsuloides bryosalmonae in kidneys of rainbow trout Oncorhynchus mykiss held at $18^{\circ} \mathrm{C}$. Results of the macroscopic and histological examination of the kidneys and presence of parasite DNA in the urine measured by real-time PCR. $(+)$ : scattered; + : mild alterations; ++: moderate alterations; +++ : severe alterations; nd: not done

\begin{tabular}{|c|c|c|c|c|c|}
\hline & & & post-exp & josure & \\
\hline & 12 & 19 & 26 & 33 & 47 \\
\hline Macroscopic enlargement of the ki & idney & $(n=1$ & & & \\
\hline Abundance & ++ & + & + to +++ & + to +++ & ++ to +++ \\
\hline Prevalence (\%) & 10 & 30 & 100 & 100 & 100 \\
\hline Histological changes to the kidneys & $\mathbf{s}(\mathbf{n}=$ & & & & \\
\hline Prevalence $(\%)$ & 100 & 100 & $100^{\mathrm{a}}$ & 100 & 100 \\
\hline Interstitium & & & & & \\
\hline Proliferation of haematopoietic tissue & + & + & + & + & + \\
\hline Infiltration & + & ++ & + & +++ & + \\
\hline Necrosis & & +++ & +++ & +++ & ++ \\
\hline Haemorrhage & & & +++ & +++ & +++ \\
\hline Parasites with daughter cells & + & ++ & +++ & +++ & +++ \\
\hline Degenerating parasites & & & & & + \\
\hline Vessels & & & & & \\
\hline Hypertrophy of endothelial cells & & + & & & \\
\hline $\begin{array}{l}\text { Infiltration with inflammatory cells } \\
\text { in vessel wall }\end{array}$ & & + & ++ & ++ & + \\
\hline Attachment of inflammatory cells & & ++ & +++ & +++ & ++ \\
\hline Parasites penetrating vessel wall & & & + & + & + \\
\hline Necrosis of vessel wall & & & + & +++ & +++ \\
\hline Thrombi & & & +++ & +++ & ++ \\
\hline $\begin{array}{l}\text { Parasites with daughter cells in lumen } \\
\text { Degenerating parasites }\end{array}$ & + & + & ++ & +++ & $\begin{array}{c}+++ \\
++\end{array}$ \\
\hline Tubules & & & & & \\
\hline Tubulonephrosis & & & + & + & + \\
\hline Intraluminal stages of parasites & $(+)$ & $(+)$ & $(+)$ & $(+)$ & $(+)$ \\
\hline Real-time PCR & nd & neg & pos & pos & pos \\
\hline${ }^{\mathrm{a}} \mathrm{n}=6$ & & & & & \\
\hline
\end{tabular}

oped into a severe necrotizing vasculitis with thrombus formation from Day 26 until the end of the experiment (Table 5, Fig. 2e,f). Within the same period, parasites were penetrating through the vessel walls and macrophages and lymphocytes surrounded intravascular parasites. In contrast to the more pronounced interstitial and vascular lesions, tubular lesions were similar to those in the $12^{\circ} \mathrm{C}$ group with only mild tubulonephrosis.

Corresponding to the more advanced histopathological lesions in interstitium and vessels, parasites with daughter cells were already visible at Day 12. By means of IHC and ISH, the localization of parasites was comparable to the $12^{\circ} \mathrm{C}$ group with highest parasite numbers in the interstitium (Table 2, Fig. 3c,d). The number of parasites in the vessels as detectable by both IHC and ISH was significantly higher in the $18^{\circ} \mathrm{C}$ group compared with the $12^{\circ} \mathrm{C}$ group at Days 26 and $33(\mathrm{p} \leq 0.05)$. The number of parasites in the interstitium was about 14 to 15 times higher compared to the $12^{\circ} \mathrm{C}$ group with a significant difference to the $12^{\circ} \mathrm{C}$ group at Days 12, 26, 33 and 47 (p $\leq$ 0.05 ; Table 2). Numbers of parasites in tubules remained low over the whole experimental period, both in the $12^{\circ} \mathrm{C}$ group and in the $18^{\circ} \mathrm{C}$ group. Small numbers of parasites were detected by ISH in the tubules by Day 12. The number of parasites found by IHC and ISH revealed significant differences between the 2 methods at all sampling points in the interstitium $(\mathrm{p} \leq 0.05)$ and at Days 33 and 47 in the lumen of the tubules ( $p \leq 0.05$ ) with more parasites detected by ISH. In the urine, parasite DNA was detectable at Days 26 and 47 (Table 4), similar to the $12^{\circ} \mathrm{C}$ group.

\section{DISCUSSION}

The pathogenesis of Tetracapsuloides bryosalmonae infection and development of pathologic lesions in the kidney with respect to water temperature are only partly understood. Further, it is not known how renal pathology relates to parasite proliferation and localization in the kidney.

The results from the present study show that fish infected with Tetracapsuloides bryosalmonae develop a severe proliferative and granulomatous nephritis. Congruent findings have been reported in previous studies 
on fish that were kept at an elevated water temperature and showed high mortalities (Kent \& Hedrick 1985, Clifton-Hadley et al. 1987), comparable to the $18^{\circ} \mathrm{C}$ group of the present investigation. However, the kidney pathological response at lower, more physiological temperatures, when PKD-related mortalities remain low, has not been studied so far. Our results indicate a proliferative and granulomatous nephritis does not only develop at high but also at low water temperature, as the type of renal lesion was found to be similar at the 2 temperatures. However, the severity of the lesions and their extent in the kidney tissue were markedly different. Additionally, severe vascular lesions observed at $18^{\circ} \mathrm{C}$, such as vascular thrombosis and rupture, were not seen in the $12^{\circ} \mathrm{C}$ group.

The question arising from the findings on temperature-related differences in the intensity of renal pathology is how parasite development in the kidney responds to the temperature difference. The key findings from the comparative examination of the intrarenal fate of the parasite at $12^{\circ} \mathrm{C}$ and $18^{\circ} \mathrm{C}$ are as follows: (1) The number of parasites was significantly higher at $18^{\circ} \mathrm{C}$ than at $12^{\circ} \mathrm{C}$. After initial infection the fish were kept in parasite-free tap water in the laboratory. It is therefore not likely that the differences in parasite loads between the 2 temperature groups resulted from parasite uptake from the environment. It is rather suggested, that the differences resulted from a temperature dependent alteration of the parasite's proliferation kinetics in the host. (2) The distribution of parasites in the renal compartments and the time course and onset of parasite degeneration were temperature independent. (3) The appearance of intraluminal parasites in the tubuli was associated with the detection of DNA in the urine. The time point of parasite DNA excretion was also temperature independent.

Because of possible changes in antigenic epitopes during parasite development, the use of ISH was included in the study as well as antigen labelling by IHC. Significant differences were found between ISH and IHC results, however these differences were found equally in both water temperature groups. Differences in the counted number of parasites by ISH and IHC could also be due to the fact that ISH identified parasites that were phagocytosed or degenerated and did not express antigens recognizable by IHC.

In conclusion, the results of this study indicate that both, proliferation of Tetracapsuloides bryosalmonae in a fish host and the renal pathological response to this infection are temperature dependent. These findings suggest that the increased fish mortality at $18^{\circ} \mathrm{C}$ is related to the increased rate of parasite proliferation and kidney dysfunction, such as impaired osmoregulation and a reduction of haematopoietic capability and haemorrhage (Roberts \& Rodger 2001, Reimschuessel
\& Ferguson 2006). These changes may turn fatal at the higher water temperature, when the fish is confronted with increased needs of renal water excretion and of blood oxygen transport. The question of whether the advanced pathology at the higher water temperature is due to a direct effect of the increased parasite load on the renal tissue or whether it is due to factors related to the fish immunity, cannot be answered from these findings. As fish are poikilothermic animals their immune system is temperature dependent (Le Morvan et al. 1997, Köllner \& Kotterba 2002, Nikoskelainen et al. 2004) so that the advanced pathological reaction especially in the interstitial tissue of the kidney might be due to an enforced immune reaction of the fish. Furthermore, while the present study focused on temperature regimes associated with significant differences in PKD manifestation to obtain insight into pathogenic processes in $T$. bryosalmonae-infected fish, the effect of smaller differences in water temperature on hostpathogen interaction remains to be investigated.

Acknowledgements. We thank U. Forster for performing the immunohistochemisty, the staff of histology laboratory of the institute for preparation of the histological sections, and P. Girling for helpful comments on the manuscript.

\section{LITERATURE CITED}

Adams A, Richards RH, De Mateo M (1992) Development of monoclonal antibodies to $\mathrm{PK}^{\prime} \mathrm{X}^{\prime}$, the causative agent of proliferative kidney disease. J Fish Dis 15:515-521

Anderson CL, Canning EU, Okamura B (1999) 18S rDNA sequences indicate that PKX organism parasitizes bryozoa. Bull Eur Assoc Fish Pathol 19:94-97

Burkhardt-Holm P, Giger W, Güttinger H, Ochsenbein U and others (2005) Where have all the fish gone? The reasons why fish catches in Swiss rivers are declining. Environ Sci Technol 39:441A-447A

Canning EU, Curry A, Feist SW, Longshaw M, Okamura B (1999) Tetracapsula bryosalmonae n.sp. for PKX organism, the cause of PKD in salmonid fish. Bull Eur Assoc Fish Pathol 19:203-206

Canning EU, Curry A, Feist SW, Longshaw M, Okamura B (2000) A new class and order of myxozoans to accommodate parasites of bryozoans with ultrastructural observations on Tetracapsula bryosalmonae (PKX organism). J Eukaryot Microbiol 47:456-468

- Clifton-Hadley RS, Richards RH, Bucke D (1986) Proliferative kidney disease (PKD) in rainbow trout, Salmo gairdneri: further observations on the effects of temperature. Aquaculture 55:165-171

Clifton-Hadley RS, Bucke D, Richards RH (1987) A study of the sequential clinical and pathological changes during proliferative kidney disease in rainbow trout, Salmo gairdneri Richardson. J Fish Dis 10:335-352

Curtis BJ, Wood CM (1991) The function of the urinary bladder in vivo in the freshwater rainbow trout. J Exp Biol 155:567-583

Feist SW, Bucke D (1993) Proliferative kidney disease in wild salmonids. Fish Res 17:51-58

Feist SW, Longshaw M, Canning EU, Okamura B (2001) 
Induction of proliferative kidney disease (PKD) in rainbow trout Oncorhynchus mykiss via the bryozoan Fredericella sultana infected with Tetracapsula bryosalmonae. Dis Aquat Org 45:61-68

Ferguson HW (1981) Effects of temperature on the development of proliferative kidney disease in rainbow trout, Salmo gairdneri Richardson. J Fish Dis 4:175-177

Ferguson HW, Ball HJ (1979) Epidemiological aspects of proliferative kidney disease in rainbow trout, Salmo gairdneri Richardson in Northern Ireland. J Fish Dis 2:219-225

Grabner DS, El-Matbouli M (2008) Transmission of Tetracapsuloides bryosalmonae (Myxozoa: Malacosporea) to Fredericella sultana (Bryozoa: Phylactolaemata) by various fish species. Dis Aquat Org 79:133-139

Hedrick RP, MacConnell E, de Kinkelin P (1993) Proliferative kidney disease of salmonid fish. Annu Rev Fish Dis 3: $277-290$

- Hedrick RP, Baxa DV, De Kinkelin P, Okamura B (2004) Malacosporean-like spores in the urine of rainbow trout react with antibody and DNA probes to Tetracapsuloides bryosalmonae. Parasitol Res 92:81-88

Hintze J (2006) NCSS, PASS, and GESS. NCSS, Kaysville, UT. Available at: www.ncss.com

Kent ML, Hedrick RP (1985) Development of the PKX myxosporean in rainbow trout Salmo gairdneri. Dis Aquat Org 1:169-182

Kent ML, Khattra J, Hervio DML, Devlin RH (1998) Ribosomal DNA sequence analysis of isolates of the PKX myxosporean and their relationship to members of the genus Sphaerospora. J Aquat Anim Health 10:12-21

Köllner B, Kotterba G (2002) Temperature dependent activation of leucocyte populations of rainbow trout, Oncorhynchus mykiss, after intraperitoneal immunisation with Aeromonas salmonicida. Fish Shellfish Immunol 12:35-48

Le Morvan C, Troutaud D, Deschaux P (1997) Differential effects of temperature on specific and nonspecific immune defences in fish. J Exp Biol 201:165-168

Longshaw M, Feist SW, Canning EU, Okamura B (1999) First identification of PKX in bryozoans from the United Kingdom-molecular evidence. Bull Eur Assoc Fish Pathol 19: 146-148

Longshaw M, Le Deuff RM, Harris AF, Feist SW (2002) Development of proliferative kidney disease in rainbow trout,

Editorial responsibility: Dieter Steinhagen,

Hannover, Germany
Oncorhynchus mykiss (Walbaum), following short-term exposure to Tetracapsula bryosalmonae infected bryozoans. J Fish Dis 25:443-449

> Morris DJ, Adams A (2006) Transmission of Tetracapsuloides bryosalmonae (Myxozoa: Malacosporea), the causative organism of salmonid proliferative kidney disease, to the freshwater bryozoan Fredericella sultana. Parasitology 133:701-709

Morris DJ, Ferguson HW, Adams A (2005) Severe, chronic proliferative kidney disease (PKD) induced in rainbow trout Oncorhynchus mykiss held at a constant $18^{\circ} \mathrm{C}$. Dis Aquat Org 66:221-226

Nikoskelainen S, Bylund G, Lilius E (2004) Effect of environmental temperature on rainbow trout (Oncorhynchus mykiss) innate immunity. Dev Comp Immunol 28:581-592

$>$ Okamura B, Anderson CL, Longshaw M, Feist SW, Canning EU (2001) Patterns of occurrence and 18S rDNA sequence variation of PKX (Tetracapsula bryosalmonae), the causative agent of salmonid proliferative kidney disease. J Parasitol 87:379-385

Reimschuessel R, Ferguson HW (2006) Kidney. In: Ferguson HW (ed) Systemic pathology of fish. Scotian Press, London, p 90-119

Roberts JR, Rodger HD (2001) The pathophysiology and systematic pathology of teleosts. In: Roberts JR (ed) Fish pathology. Harcourt Publishers Limited, London, p 55-132

Sterud E, Forseth T, Ugedal O, Poppe TT and others (2007) Severe mortality in wild Atlantic salmon Salmo salar due to proliferative kidney disease (PKD) caused by Tetracapsuloides bryosalmonae (Myxozoa). Dis Aquat Org 77: 191-198

> Wahli T, Knüsel R, Bernet D, Segner H and others (2002) Proliferative kidney disease in Switzerland: current state of knowledge. J Fish Dis 25:491-500

Wahli T, Bernet D, Steiner PA, Schmidt-Posthaus H (2007) Geographic distribution of Tetracapsuloides bryosalmonae infected fish in Swiss rivers: an update. Aquat Sci 69:3-10

- Yin JL, Shackel NA, Zekry A, McGuinness PH and others (2001) Real-time reverse transcriptase-polymerase chain reaction (RT-PCR) for measurement of cytokine and growth factor mRNA expression with fluorogenic probes or SYBR Green I. Immunol Cell Biol 79:213-221

Submitted: June 11, 2008; Accepted: September 22, 2008 Proofs received from author(s): December 22, 2008 